\title{
16: 70665292-70668646
}

National Cancer Institute

\section{Source}

National Cancer Institute. 16: 70665292-70668646. NCI Thesaurus. Code C42488.

Physical location of HPR_Gene 